\title{
Alienation on Social Media
}

\begin{abstract}
Sandro Serpa
Correspondence: Sandro Serpa, Department of Sociology, Faculty of Social and Human Sciences, University of the Azores, Interdisciplinary Centre of Social Sciences-CICS.UAc/CICS.NOVA.UAc and Interdisciplinary Centre for Childhood and Adolescence—NICA—UAc, 9501-801 Ponta Delgada, Portugal.
\end{abstract}

Received: April 27, 2019

doi:10.11114/smc.v7i1.4286

\author{
Accepted: May 22, 2019 \\ Online Published: May 24, 2019 \\ URL: https://doi.org/10.11114/smc.v7i1.4286
}

\begin{abstract}
Digital technology has a growing dominance in social relationships. This opinion paper aims, through a selection of information deemed relevant on this topic, to offer a reflection on alienation in the context of social media, as well as, to the extent possible, some of its implications.
\end{abstract}

Keywords: alienation, social media, social relationships.

"While democracy is losing its way

And greed is getting greedier

Console yourself with a selfie or two

And post them on social media [...]

It's so nice when people like you

You're feeling hashtag blessed

You're part of the conversation

It's like you passed the test"

(Pet Shop Boys, On Social Media, 2019)

\section{Introduction}

As will be seen throughout this text, the part of its title On Social Media is taken from the title of a song from the musical duet Pet Shop Boys (composed of Christopher Lowe and Neil Tennant), which has recently been released, in 2019 (Pet Shop Boys, 2019; Low \& Tennant, 2019).

My specific interest in this song as the starting point for this reflection is based on three main reasons, each with its specific relative importance: (i) personal taste, which makes me follow the work of this music band since 1984; (ii) the fact that my preteenager son told me: "this song seems current", which increased my attention for this song (the music but, mainly, the lyrics and the video); and (iii) my interest in the scientific study of the influence of social networks on the interactions between individuals, favouring a sociological perspective (Serpa \& Ferreira, 2018).

The reasons set out above inspired me in the preparation of this text, which is, itself and intentionally, assumedly unorthodox in comparison with the usual academic papers. Thus, this opinion paper, inserted in a context where the digital technology has an increasing relevance in the social relationships, aims, through a selection of information deemed relevant on this topic, to put forward a reflection on alienation in the social media context, as well as, to the extent possible, some of its implications.

\section{Alienation and social Media}

Although this paper does not exactly aim to discuss the concept of alienation, it is undeniable that it has been profusely mobilised over the last century in the disciplinary fields of Philosophy and Social Science (Aron, 1994; Silver, 2018; Harvey, 2018), although, more recently, it has been less used and has lost some visibility (Silver, 2018; Tairako, 2018).

Karl Marx was one of the most important contributors to the use of this concept of alienation (Raekstad, 2015). According to the author, alienation may be considered as the lack of awareness, by the members of a social class, of their social role in history. As Marx points out in A Contribution to the Critique of Political Economy, in 1859,

The totality of these relations of production constitutes the economic structure of society [infrastructure], the real foundation, on which arises a legal and political superstructure and to which correspond definite forms of 
social consciousness. The mode of production of material life conditions the general process of social, political and intellectual life. It is not the consciousness of men that determines their existence, but their social existence that determines their consciousness (in Cruz, 1989, pp. 73 and 74).

In this perspective, which values the activity of production in the formation and reproduction of alienation, and stressing the existence of a profusion of analyses of Karl Marx's work (Aron, 1994; Silver, 2018; Tairako, 2018; Harvey, 2018; Adibifar, 2016), Tairako (2018) argues that the theory of alienation entails a set of transformations, of which the author highlights:

(1) the transformation of relations of persons to persons in the production into those of things to things (the first phase of the alienation=externalization of private property, namely reification), (2) the transformation of relations of things to things into material properties of labor products (the second phase of the alienation=externalization of private property, namely thingification), and (3) the transformation of property of a thing from value or equivalent to money, and further to capital. The last transformation is characterized as an increase of the dominion of things or products over the laborer or labor (p. 14).

As Raekstad (2015) states with regard to Marx's proposal, he distinguishes four types of alienation:

alienation from the product of labour consists in the fact that, under capitalism, workers reproduce and strengthen certain social structures that keep them in bondage; one of the implications of these social structures is that one's work and its content are determined by factors outside and seemingly independent of the workers themselves (alienation from labour); the fact that this occurs in productive activity means that workers in such societies are alienated from their internal ability for conscious self-directed activity (alienation from one's essence as a species-being); and humans under such conditions are alienated from other humans because the abovementioned forms of alienation entail, in a certain way, the existence of another specific role which must be filled, namely the role of the capitalist, who comes to own the alienated products and labour as loci of power over workers, and from whom workers are, therefore, alienated (alienation from other human beings) [emphasis added] (p. 313).

However, in order to increase its heuristic ability to interpret the current social reality, it seems pertinent to us the stance which advocates that alienation has to be a broader multidimensional concept than the perspective provided by Marx, which focuses on alienation in the relationship between capital and labour (Tairako, 2018; Silver, 2018; Raekstad, 2018). The reflection carried out in this paper seeks to discuss the updating of a proposal on alienation - "alienation, grounded in an acknowledgment of contingency and pluralism: there is no single ultimate source of alienation, and alienation may emerge through multiple combinations of diverse factors" (Silver, 2018, p. 85). Furthermore, it also seeks to establish an interconnection between the macro-, meso- and micro-social levels (Silver, 2018; Harvey, 2018; Serpa \& Ferreira, 2019).

Akoun (1990, p. 15) maintains that the concept of "Alienation" may have the more general meaning of "transformation of man's specific activity into a power that would be strange to him and which dominates him". The strangeness (Javeau, 1998) of man before himself and his activity is a key feature of alienation.

However, as Harvey (2018) points out, alienation is present everywhere and permeates all contexts where social interaction takes place. Still according to Harvey (2018, p. 428), "Alienated wage labour may be offset by compensatory consumerism". This may occur in a context where the application of digital and information/communication technologies is intensified, given that, as Adibifar (2016) suggests, "Technology can also be defined as knowledgeability and ability to apply any types of machine in any form and shape in interaction, operation, and production to achieve an objective" (p. 62).

Adibifar (2016) reminds us that the relationship between alienation and technology is a very complex one.

Marx alienation is mostly relevant to production, but I perceive consumption, particularly consumption of technology, as a core agent of alienation. Generally, alienation as a psychological condition that refers to the breakdown of the natural interconnection among people and their production and feeling of disconnectedness from social settings as the individual views his/ her relationships from social context as no longer reasonable (Adibifar, 2016, p. 64).

The presence of technology, which is reinforced, for example, in the framework of Society 5.0 (Ferreira \& Serpa, 2018), is materialised in diverse aspects. In this regard, Adibifar (2016) argues that

People may use the internet to seek partners, do research, establish contact with others, or even seek family and social support. With electronic mail (email), social networking websites, and text messages, face-to-face conversation is becoming more obsolete. Instead of taking time to call someone or write letters to family, many people send text messages that barely make grammatical sense. It is true that technology has made it easier for 
people to interact, but it also has and continues to diminish the value of human communication (p. 64).

This difficulty in being able to consciously deal with the presence of technology, namely in the context of social media, is added to other hindrances, such as the issue of digital literacy (Santos \& Serpa, 2017). This is justified by the fact that "People who lack the knowledge and skills of information technology cannot compete in the current model of globalization and techno-industrial society. This in turn diminishes their importance and their social status, resulting in alienation" (Adibifar, 2016, p. 65).

\section{Conclusion}

In this context of growing influence of technology on our social life, in which the potential increase and/or variation of alienation is expanding (Kutubidze, 2019), the sociologist has "the responsibility of maintaining a clear, insightful and constantly renewed awareness of the impetus that drives any society and the objectives that it pursues" (Rocher, 1989, p. 252). As the eternal Norbert Elias (2011) states,

when creating or criticising sociological theories, to what extent I am essentially trying to establish the validity of a preconceived idea of how human societies should be ordered? Secondly: to what extent do I accept the results of theoretical and empirical research that will confirm my own objectives and hopes, not taking into account those who are incompatible with them? Thirdly: to what extent am I primarily concerned with finding connections between particular social events, understanding how we can explain their sequence? And finally: what help can sociological theories give to the explanation and determination of the course of social problems and to what extent am I interested in finding practical solutions for them? (pp. 167-168).

In this context of deconstructing preconceived ideas and "making more accessible to human understanding these blind and uncontrolled processes, explaining them and allowing people guidance within the social web" (Elias, 2011, p. 168), Sociology can provide instruments of analysis, understanding and deconstruction of social alienation (Ferreira \& Serpa, 2017) and, ultimately, provide individuals with an awareness, always respecting their autonomy, and understand the reasons, as well as the implications of considering that "When you're on Social media . . [you] feel so empowered" (Pet Shop Boys, 2019; Lowe \& Tennant, 2019).

\section{Acknowledgment}

I would like to thank to the Reviewers for their comments and suggestions.

\section{Funding}

University of Azores, Interdisciplinary Centre of Social Sciences_CICS.UAc/CICS.NOVA.UAc, UID/SOC/04647/2013, with the financial support of the FCT/MEC through national funds and when applicable co-financing from the FEDER under the PT2020 Partnership Agreement.

\section{References}

Adibifar, K. (2016). Technology and alienation in modern-day societies. International Journal of Social Science Studies, 4(9). https://doi.org/10.11114/ijsss.v4i9.1797

Akoun, A. (1990). Alienação [Alienation]. In R. Boudon, P. Besnard, M. Cherkaoui, \& B.-P. Lécuyer (Dirs.), Dicionário de sociologia [Dictionary of sociology] (p. 15). Lisboa: Publicações Dom Quixote.

Aron, R. (1994). Karl Marx. In As etapas do pensamento sociológico [The stages of sociological thinking] (pp. 139215). Lisboa: Publicações Dom Quixote.

Cruz, M. B. (1989). Karl Marx - Friedrich Engels. In Teorias sociológicas (colectânea de textos) [Sociological theories (compendium of texts)] (pp. 3-136). Lisboa: Fundação Calouste Gulbenkian.

Elias, N. (2011). Introdução à sociologia [Introduction to sociology]. Lisboa: Edições 70.

Ferreira, C. M., \& Serpa, S. (2017). Challenges in the teaching of sociology in higher education. Contributions to a discussion. Societies, 7(4), 30. https://doi.org/10.3390/soc7040030

Ferreira, C. M., \& Serpa, S. (2018). Society 5.0 and social development: Contributions to a discussion. Management and Organizational Studies, 5(4), 26. https://doi.org/10.5430/mos.v5n4p26

Harvey, D. (2018). Universal alienation. tripleC, 16(2), 424-439. https://doi.org/10.31269/triplec.v16i2.1026

Javeau, C. (1998). Lições de sociologia [Lessons in sociology]. Oeiras: Celta Editora.

Kutubidze, I. (2019). Economic growth: Scientific-technical progress and alienation of people. Ecoforum, 8, 1-18.

Lowe, C., \& Tennant, N. (2019). On social media, Pet Shop Boys (2019). Available at https://www.google.com/search?q=on+social+media+pet+shop+boys+lyrics\&oq=on+social+media+pet+shop+boy 
s+lyrics\&aqs=chrome..69i57j69i60.746j0j8\&sourceid=chrome\&ie=UTF-8. Accessed on April 26, 2019.

Pet Shop Boys-On social media (lyrics video) (2019). Available at https://www.youtube.com/watch?v=UuNBJkLLnOs. Accessed on April 26, 2019.

Raekstad, P. (2015). Human development and alienation in the thought of Karl Marx. European Journal of Political Theory, 17(3), 300-323. https://doi.org/10.1177/1474885115613735

Rocher, G. (1989). Sociologia geral. Mudança social e acção histórica [General sociology. Social change and historical action] (Vol. III). Lisboa: Editorial Presença.

Santos, A. I., \& Serpa, S. (2017). The importance of promoting digital literacy in higher education. International Journal of Social Science Studies, 5(6), 90. https://doi.org/10.11114/ijsss.v5i6.2330

Serpa, S., \& Ferreira, C. M. (2018). Goffman's backstage revisited: Conceptual relevance in contemporary social interactions. International Journal of Social Science Studies, 6(10), 74. https://doi.org/10.11114/ijsss.v6i10.3659

Serpa, S., \& Ferreira, C. M. (2019). Micro, meso and macro levels of social analysis. International Journal of Social Science Studies, 7(3), 120. https://doi.org/10.11114/ijsss.v7i3.4223

Silver, D. (2018). Alienation in a four factor world. Journal for the Theory of Social Behaviour, 49, 84-105. https://doi.org/10.1111/jtsb.12192

Tairako, T. (2018). Reification-thingification and alienation-basic concepts of Marx's critique of political economy and practical materialism. Hitotsubashi Journal of Social Studies, 49, 1-28.

\section{Copyrights}

Copyright for this article is retained by the author(s), with first publication rights granted to the journal.

This is an open-access article distributed under the terms and conditions of the Creative Commons Attribution license which permits unrestricted use, distribution, and reproduction in any medium, provided the original work is properly cited. 